\title{
PENGARUH GAYA MENGAJAR INKLUSI DAN KOORDINASI TERHADAP HASIL BELAJAR LOMPAT JANGKIT SISWA SMA ANGKASA 1 MEDAN
}

\author{
Rizki Bastanta B. Manalu \\ Universitas Quality Berastagi \\ Email : $\underline{w w w . u q b . a c . i d}$ bastanta.rizki@gmail.com
}

Tlp : 081376633745

\begin{abstract}
Abstrak
Tujuan dari penelitian ini adalah untuk mengetahui pengaruh dari gaya mengajar Inklusi dan koordinasi terhadap Hasil Belajar Lompat Jangkit. Penelitian ini dilakukan pada siswa SMA ANGKASA 1 Medan, penelitian ini menggunakan metode eksperimen. Sampel terdiri dari 20 orang siswa yang dibagi menjadi 2 kelompok, masing-masing terdiri dari 10 siswa. Teknik analisis data adalah analisis varians dua jalur (ANAVA) dan selanjutnya dilanjutkan dengan Uji tukey pada tingkat signifikasi $a=, 05$. Hasil penelitian ini menunjukan bahwa (1) Gaya mengajar inklusi memiliki pengaruh yang lebih baik dari pada gaya mengajar latihan terhadap Hasil Belajar Lompat Jangkit yang memiliki koordinasi tinggi.
\end{abstract}

Kata kunci: Hasil Belajar Lompat Jangkit, Koordinasi, Gaya Mengajar Inklusi.

\begin{abstract}
The purpose of this research was to determine the effect of teaching style Inclusion and coordination to Learning Outcomes Triple Jump. Research was conducted on students of SMA ANGKASA 1 Medan, this research used treatment experimental method. The sample consisted of 20 students who were divided into 2 groups, which there 10 students. Analysis data taken by ANOVA and Tukey test continued with the level of significance $a=.05$. These results indicate that (1) The style of teaching inclusions have a better effect than the teaching styles of exercise on learning outcomes Triple Jump which have high coordination.
\end{abstract}

Keywords: Learning Outcomes Triple Jump , Coordination, Inclusion Teaching Style.

Dipublikasikan Oleh :

UPT Publikasi dan Pengelolaan Jurnal

Universitas Islam Kalimantan Muhammad Arsyad Al-Banjari Banjarmasin 


\section{PENDAHULUAN}

Sekolah merupakan lembaga pendidikan yang mempunyai tugas untuk menghantarkan peserta didik mengembangkan segala potensi yang dimilikinya. Sekolah juga dipercaya sebagai satu-satunya cara agar manusia pada zaman sekarang dapat hidup lebih baik dimasa yang akan datang. Keberhasilan pendidikan di sekolah sangat tergantung pada proses belajar mengajar di kelas. Kegiatan belajar mengajar bertujuan untuk membawa peserta didik pada perubahan tingkah laku yang diinginkan. Pengertian ini kelihatan cukup simpel dan sederhana, akan tetapi bila pengertian ini ditelaah lebih dalam, maka akan terlihat lebih rumit dan begitu kompleksnya proses yang dituntut dalam mengelola pelajaran itu sendiri. Hal ini bisa dipahami karena membawa peserta didik ke arah perubahan yang diinginkan. Dalam proses pembelajaran di sekolah terdapat banyak unsur yang saling berkaitan dan menentukan dalam proses belajar mengajar. Unsur-unsur tersebut adalah pendidik (guru), peserta didik (siswa), kurikulum pengajaran, tes dan lingkungan. Siswa sebagai subjek dalam proses pembelajaran tersebut juga sangat berperan dalam keberhasilan belajar mengajar. Salah satu tugas pendidik atau guru adalah menciptakan suasana proses pembelajaran yang dapat memotivasi siswa untuk senantiasa belajar dengan baik dan bersemangat. Suasana pembelajaran yang demikian akan berdampak positif dalam pencapain prestasi belajar yang optimal, sehingga dapat membuat siswa semangat dan tekun belajar. Pendidikan Jasmani (Penjas) adalah usaha pendidikan dengan menggunakan aktivitas otot-otot besar sehingga proses pendidikan yang berlangsung tidak terhambat oleh gangguan kesehatan dan pertumbuhan badan. Sebagai bagian integral dari pendidikan keseluruhan, pendidikan jasmani merupakan usaha yang bertujuan untuk mengembangkan kawasan organik, neuromuskuler, intelektual dan sosial.

Dalam pembelajaran lompat jangkit guru pendidikan jasmani di SMA ANGKASA 1 Medan ini selalu berusaha menyajikan pembelajaran dengan baik dengan melakukan pengembangan program Pendidikan jasmani, olahraga dan kesehatan sesuai kurikulum dan melaksanakan pembelajaran berdasarkan rencana pembelajaran, selain itu guru juga dalam proses pembelajaran Pendidikan jasmani, olahraga dan kesehatan membantu siswa bergerak lebih terarah dalam ruang gerak yang kecil.

Namun dalam pelaksanaan pembelajaran Pendidikan jasmani, olahraga dan kesehatan dengan menerapkan teknik modifikasi masih terdapat kekurangan dan diperlukan adanya perbaikan, khususnya pada pembelajaran lompat jangkit antara lain kurangnya pendekatan guru terhadap siswa dalam proses pembelajaran dan kurang aktifnya siswa pada saat pembelajaran, sedangkan yang seharusnya pembelajaran pendidikan jasmani, olahraga dan kesehatan terutama dalam kurikulum 2013 lebih menekankan keaktifan siswa dalam pembelajaran dan bukan sebaliknya sehingga di dalam proses pembelajaran terdapat nilai - nilai semangat, sportivitas, percaya diri dan kejujuran pada materi pembelajaran lompat jangkit bagi kelas XI SMA ANGKASA 1 Medan.

\section{a. Gaya mengajar}

Salah satu aspek pendidikan yang senantiasa dikembangkan melalui penelitian adalah proses pengajaran, serta upaya untuk menghasilkan model - model pengajaran yang tepat. Pada dasarnya diperlukan suatu teori pengajaran yang bersifat universal yang difokuskan pada pengajaran sebagai satu aspek tingkah laku manusia berdiri sendiri. Teori pengajaran harus selalu menyertakan semua fenomena dan kondisi dari semua unsur yang terintegrasi dalam kegiatan sebenarnya.

Usaha untuk mencapai suatu tujuan di dalamnya manusia dituntut untuk menggunakan strategi dalam prosesnya agar pencapaian tujuan lebih efektif dan efisien, tentunya hal ini berlaku pula di dalam suatu proses pembelajaran. Strategi yang dimaksud adalah strategi pembelajaran yang mencakup gaya mengajar pembelajaran, penggunaan media pembelajaran, guru sebagai fasilitator, siswa sebagai subyek pembelajaran, dan situasi di lingkungan belajar atau situasi belajar yang kesemuanya itu merupakan pusat perhatian dalam pembelajaran. Pembelajaran dikatakan berhasil dengan baik apabila didalamnya menggunakan berbagai sumber yang sifatnya terbatas namun memperoleh yang tepat, cermat dan optimal disamping perlu pula diperhatikan tingkat keterlibatan siswanya.

b. Hasil Belajar

Belajar merupakan suatu proses yang ditandai dengan adanya perubahan pada diri seseorang sebagai hasil dari pengalaman dan latihan. Dalam proses pendidikan sendiri hasil belajar adalah seluruh kecakapan yang dicapai melalui proses belajar mengajar yang dinyatakan dengan angka - angka atau nilai yang di ukur dengan tes hasil belajar. Perubahan sebagai hasil dari belajar dapat ditimbulkan dalam 
berbagai bentuk, seperti berubahnya pengetahuan, pemahaman, sikap dan tingkah laku,kecakapan serta kemampuan.

\section{c. Koordinasi}

Koordinasi adalah salah satu unsur kondisi fisik yang diperlukan dalam usaha meningkatkan prestasi. Menurut Sukadiyanto koordinasi merupakan perpaduan kinerja dari kualitas otot, tulang dan persendian dalam menghasilkan satu gerak yang efektif dan efisien. Komponen biomotor koordinasi sangat diperlukan hampir setiap cabang olahraga melibatkan sinkronisasi dari beberapa kemampuan.

\section{d. Keterampilan Lompat Jangkit}

Lompat jangkit merupakan salah satu nomor atletik yang diperlombakan baik di tingkat nasional maupun di tingkat internasional. Sekaligus salah satu materi yang diajarkan di Sekolah Menengah Atas maupun Kejuruan. Lompat jangkit yang biasa disebut hop, step dan jump adalah sebuah olahraga trek and field (melibatkan jalur di lapangan) mirip dengan lompat jauh, tetapi melibatkan rutinitas "jingkat (hop), langkah (step), lompat (jump)", dimana pesaing berjalan menyusuri jalur dan melakukan satu jingkatan (hop), satu langkah (step) dan kemudian melompat (jump) ke dalam kotak pasir. Di dalam lompat jangkit sebenarnya terjadi tiga kali tolakan, tiga kali melayang di udara, dan tiga kali pendaratan. Jarak lompatan di ukur dari kumulatif ketiga gerakan lompat jangkit tersebut (hop-stepjump).

Gerakan lompat jangkit memproyeksikan pusat gaya berat tubuh si pelompat di udara ke arah depan dengan melalui tiga tahapan lompatan atau tumpuan. Yaitu hop, step, jump. Menurut ketentuan si pelompat harus melakukan, menumpu dua kali dengan kaki yang sama yang disebut step dan diakhiri dengan gerakan jump atau lompat. Hasil dari suatu lompatan sangat tergantung dari kecepatan horizontal dan kekuatan pada ketiga tahapan tumpuan tersebut. Jarak antara hop, step, jump bervariasi tergantung dari kecepatan, kekuatan, dan kelentukan otot. Sudut tumpuan yang tepat sangat membantu menjaga kecepatan.

\section{METODE}

Tempat penelitian ini dilakukan di lapangan lompat jauh sekolah SMA ANGKASA 1 Medan. Waktu penelitian dilaksanakan setelah keluar surat ijin penelitian. Diperkirakan waktu pelaksanaan penelitian dengan melalui tahapan : (1) Ujicoba Instrumen tanggal 26 sampai 28 Februari 2019, (2) Penelitian atau treatment dilaksanakan mulai 4 Februari sampai tanggal 5 April 2019, (3) kemudian dilanjutkan dengan pengumpulan data keterampilan lompat jangkit sebagai tes akhir. Metode yang dipergunakan dalam penelitian ini adalah metode eksperimen lapangan.

\section{HASIL DAN PEMBAHASAN}

Uraian deskripsi data hasil penelitian bertujuan untuk melihat secara umum gambaran karakteristik Hasil Belajar Lompat Jangkit yang menjadi subjek dalam penelitian ini. Hasil Belajar Lompat Jangkit dalam dua kelompok perlakuan berdasarkan gaya mengajar inklusi, Koordinasi (tinggi dan rendah) dan skor penampilan Hasil Belajar Lompat Jangkit dari masing-masing kelompok perlakuan dijelaskan pada tabel berikut ini:

Tabel. Rangkuman Data Hasil Penelitian

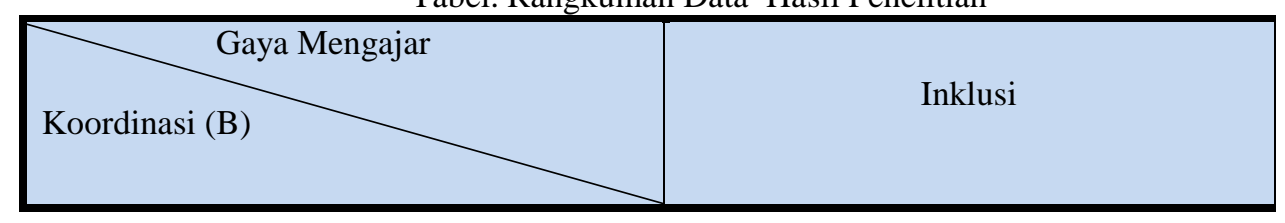

Dipublikasikan Oleh : 


\begin{tabular}{|c|c|}
\hline Tinggi & $\begin{array}{cc}\mathrm{n} & =10 \\
\overline{\mathrm{X}} & =17.00 \\
\Sigma \mathrm{X} & =170 \\
\Sigma \mathrm{X}^{2} & =2916 \\
\mathrm{SD} & =1,70\end{array}$ \\
\hline Rendah & $\begin{array}{cc}\mathrm{n} & =10 \\
\overline{\mathrm{X}} & =15.70 \\
\Sigma \mathrm{X} & =157 \\
\Sigma \mathrm{X}^{2} & =2509 \\
\mathrm{SD} & =2,21\end{array}$ \\
\hline Total & $\begin{array}{cc}\mathrm{n} & =20 \\
\overline{\mathrm{X}} & =16.35 \\
\Sigma \mathrm{X} & =327 \\
\Sigma \mathrm{X}^{2} & =3425 \\
\mathrm{SD} & =2,03\end{array}$ \\
\hline
\end{tabular}

Tabel. Rangkuman hasil uji normalitas keseluruhan data

\begin{tabular}{|c|c|c|c|c|}
\hline Kelompok & $\mathbf{N}$ & Lo & Lt & Kesimpulan \\
\hline 1 & 10 & 0,178 & 0,280 & Normal \\
\hline 2 & 10 & 0,089 & 0,280 & Normal \\
\hline
\end{tabular}

\section{Uji Homogenitas}

Pengujian homogenitas mengenai pada masing-masing kelompok perlakuan, dilakukan dengan Uji Bartlett pada taraf signifikan $\alpha=0,05$. Perhitungan uji homogenitas data Hasil Belajar Lompat Jangkit secara lengkap dapat dilihat pada lampiran, halaman rangkuman hasil perhitungan uji homogenitas pada masing-masing kelompok dilihat pada tabel di bawah ini.

Tabel. Rangkuman hasil perhitungan uji Bartlett $\alpha=0,05$

\begin{tabular}{|c|c|c|c|c|c|}
\hline Kelompok & Variansi & $\begin{array}{c}\text { Variansi } \\
\text { Gabungan }\end{array}$ & $\chi^{2}{ }_{\text {hitung }}$ & $\chi_{\text {tabel }}^{2}$ & Kesimpulan \\
\hline 1 & 2,89 & 4,775 & 1,370 & 7,82 & Homogen \\
\hline
\end{tabular}

\section{PENUTUP}

\section{Kesimpulan}

Berdasarkan hasil analisis data, hasil pengujian hipotesis dan hasil pembahasan penelitian yang telah diperoleh maka dapat dijelaskan beberapa kesimpulan, implikasi penelitian dan saran sebagai berikut:

1. Bagi siswa yang memiliki koordinasi tinggi, pemberian gaya mengajar inklusi memberikan pengaruh yang lebih baik terhadap hasil belajar lompat jangkit.

2. Bagi siswa yang memiliki koordinasi rendah, gaya mengajar inklusi kurang memberikan pengaruh terhadap hasil belajar lompat jangkit. 


\section{Saran}

Berdasarkan kesimpulan dan implikasi penelitian yang telah dikemukakan sebelumnya, maka dapatlah diajukan beberapa saran dalam penelitian ini, sebagai berikut:

- Bagi para guru pendidikan jasmani dan pelatih dapat mengetahui tentang gaya mengajar inklusi yang benar-benar cocok sesuai dengan karakteristik materi yang akan diajarkan maupun karakteristik peserta didiknya. Selain dalam menggunakan gaya mengajar hendaknya mempertimbangkan tingkat koordinasi yang dimiliki peserta didik sehingga benar-benar dapat meningkatkan hasil belajar, khusus siswa yang memiliki koordinasi tinggi disarankan agar menggunakan gaya mengajar inklusi sebagai upaya untuk meningkatkan hasil belajar.

- Kepada para staf pengajar, guru pendidikan jasmani dan pelatih didalam membina olahraga khususnya dalam keterampilan lompat jangkit hendaknya menerapkan gaya mengajar dan koordinasi sehingga benar-benar para siswa dapat meningkatkan keterampilan gerak lompat jangkit.

\section{REFERENSI}

Allen L. Edwards, Experimental Design in Physical Research Fifth Edition (New York: Harper \& Row, Inc., 1985)

Azwar, "Pengaruh Gaya Mengajar dan Motor Educability Terhadap keterampilan Tendangan T Pencak Silat” Tesis (Jakarta: PPs Universitas Negeri Jakarta, 2014)

B.E Rahantoknam, Guru Pendidikan Jasmani sebagai Fasilitator, dalam semiloka pola system operasional pendidikan jasmani sebagai basis pembinaan prestasi olahraga Indonesia menjelang globalisasi (Jakarta: 1997)

Cecco dan Crawford dalam Richard Decaprio, Aplikasi Teori Pembelajaran Motorik Di Sekolah (Jogjakarta: Diva Press, 2013)

Cecile Reynaud, Coaching Volley Ball Technical and Tactical Skills (Amerika: Education Program, 2011)

Certification System (CECS), jumping Event, Textbook, Level I - II, Development Programme. 2000.

Dinata Marta, Dasar-dasar Mengajar Atletik (Lampung : Cerdas Jaya,2003)

Experience Third Edition (California: Wadsworth Publishing Company Belmont, 1998)

Frank M. Verducci, Measurement Concepts in Physical Education (St. Louis Missouri: Mosby Company, 1980)

Fred N. Kerlinger, Azas-azas Penelitian Behavioral : Terjemahan Landung R. Simatupang (Yogyakarta: Gadjah Mada University Press, 1995)

Gerry A. Carr, 2003. Atletik untuk Sekolah. Jakarta : PT. Raja Grafindo Persada http://findarticles.com/articel, diunduh 9 november 2015.

Husdarta dkk, Belajar dan Pembelajaran Pendidikan Jasmani dan Kesehatan (Bandung: Alfabeta Bandung, 2010)

International Association of Athletics Federation, Coaches Education and

Irawadi, Kondisi Fisik dan pengukurannya. (Fakultas Ilmu Keolahragaan Universitas Negeri Padang, 2011)

Joanne Thatcher et al., Sport And Exercise Science (Brtihis Library Cataloguing in Publication Data, 2009)

JS.Husdarta dan Yudha M. Saputra, Belajar dan Pembelajaran Pendidikan Jasmani dan Kesehatan, (Alfabeta, 2013)

Kemenegpora Republik Indonesia, Undang-Undang Republik Indonesia No. 3 Tahun 2005 Tentang Sistem Keolahragaan Nasional, (Jakarta: Kemenegpora, 2005)

Dipublikasikan Oleh :

UPT Publikasi dan Pengelolaan Jurnal

Universitas Islam Kalimantan Muhammad Arsyad Al-Banjari Banjarmasin 